AÜIFD Cilt XLIII (2002) Sayl 1 s. 123-134

\title{
İlahiyat Fakülttesi Öğrencilerinin Din Anlayışı Ölçeği Üzerine Bir Pilot Araştırma
}

\author{
Niyazi AKYÜZ \\ Yrd. Doç. Dr., Ankara Üniversitesi İlâhiyat Fakültesi \\ e-mail: akyuz@divinity.ankara.edu.tr
}

Prelıminary Investigation On The Religious Understandıng Scale Of The Students Of Divintty Faculty. This study aims at improving a scale to determin the religious understanding of the students of divinity faculty. The scale consists of 20 questions. At the factor analysis made by the SPSS program, data are firstly examined by the principal components analysis and after a rotation, the number of the factors and the eigenvalues are searched. With respect to results, it is understood that there are three factors giving over 1.264 and these three factors explain the $42.8 \%$ of total variance. These three factors are named by us as follows:

1. The Dimension of Traditional-Catechism Understanding

2. The dimension of Political-İslamic Understanding

3. The dimension of Modernist Understanding.

It is considered that these dimensions show that The religious understanding of the students of divinity faculty.

Key words: Religious Mentality, The Students of Divinity Faculty, Factor Analysis. 


\section{A. GíRiş}

İnsan toplumsal bir varlıktır. Bu özellik, onun diğer varlıklardan farklı olduğunu ifade eder. İnsanın toplumsal bir varlık olmasının kapsam alanı, düşünülenden ve zannedildiğinden daha geniştir. Çünkü insan, birlikte olduğu diğer varlıklarla ihtiyacı olmaksızın ilişki temellerine de sahip olabilmektedir. Toplumsal süreç içinde insan, toplumsal hayat tecrübesinin tabii bir sonucu olarak diğer varlıklarla çeşitli ortak ve farklı niteliklere sạhip olmakta ve bu ortak ve farklı nitelikler onu, toplum içerisinde bazılarıyla bir arada bulunmaya, diğer bazılarından uzak durmaya sevk etmektedir (toplumsal mesafe, 'mesleki mobilitede ya da çeşitli etnik grupların mahremiyet sınırlarını hangi mesafede çizmeye istekli olduklarını gösteren toplumsal değişkenlere ya da ağlara dayalı benzerlik ya da yakınlık-uzaklı̆̆ı' ifade eder (G. Marshall, Sosyoloji Sözlüğü, Çev.: O. Akınhay, D. Kömürcü, Bilim ve Sanat Yayınları, Ankara 1999, 750). Toplumda insanlar arasında çeşitli faktörlerin etkisiyle meydana gelen bu toplumsal mesafeler, onların gruplaşmalarına yol açmaktadır. Bu gruplaşmalar yoluyla fert, toplum içerisinde başka yollarla gideremediği toplumsal ihtiyaçlarını gidermektedir. Ferdin bu gruplaşmalara gitmesinde veya bu gruplaşmalar arasında yerini belirlemesinde hem toplum içindeki çeşitli süreçler hem de ferdin toplumla kurduğu iletişim noktaları ya da temaslar etkilidir. İnsanın toplum içinde kurduğu bu dünyanın oluşumu bizi insanın varlık alemine gelişine dikkatimizi yöneltmeye itmektedir.

İnsan olmanın biyolojik süreci, hem fizik hem de beşeri dünyayı içine alan bir dış çevre ile etkileşim sırasında oluşur. Yani bu biyolojik temel, şahsiyet oluşumu anlamında insan olma süreciyle gerçekleşir. Sonraki gelişmeler, insanın bu biyolojik temeli üzerine bina edilir. İnsanın dünyası (diğer canlıların dünyalarıyla karşılaştırıldığında) eksik bir dünyadır, yani insan tarafından tamamlanmaya muhtaçtır. İnsan kendi kendine bir dünya oluşturmak zorundadır. Bu açıdan, insanın dünya kurma çabası, biyolojik yapısının zorunlu bir sonucudur (P. L. Berger, Dinin Sosyal Gerçekliği, Çev.: A. Coşkun, İnsan Yayınları, İstanbul 1993, 31).

Bireyin fizik çevresi ve dünyası, içinde yaşadığı toplumun kültürü, yani yaşam ve düşünce biçimi ile özdeşleşmiştir. Bireyin biyolojik bir varlık olmanın ötesine geçip bir dünya kurması, o toplumun kültürünü öğrenmesi ile mümkün olur. İşte bu öğrenme sürecine 'sosyalleştirme', sonuçta ortaya çıkan olgusal yapıya 'sosyalleşme' denir (B. Tolan, Toplum Bilimlerine Giriş, Savaş Yayınları, Ankara 1983, 347). Toplumun, sosyalleştirme sonucunda oluşturduğu kültür hayatı, aynı zamanda onun bireyler için geliştirdiği iletişim vasıtaları ve bilgi edinme, öğrenme ve öğrendiklerini aktarma sistemleri sayesinde bilgi dokularını da oluşturur.

Toplumun nesnel bilgi dokulan bütün toplum üyeleri tarafından paylaşılmakla beraber bu durum, bireyin diğer şahısları ve eşyayı aynı şekilde algıladığı anlamına gelmemektedir. Çünkü bireyin bu algıları, onların kendine görünüş tarzına, yani 'kognitif alemi'ne göre şekil alır. Her 
insanın dünya hakkında bireysel bir tasavvuru mevcut olup bu tasavvurları birbirinden farklıdır. Bu tasavvur: (1) Bireyin fizik ve sosyal çevresine, (2) Fizyolojik yapısına, (3) İstek, hedef ve amaçlarına, (4) Geçmiş tecrübelerine bağlıdır (D. Krech, R. S. Crutchfield, E. L. Ballachey, Cemiyet İçinde Fert, C. II, M. E. Basımevi, İstanbul 1983, 25-26). Nesneleri ve insanları algılarken işleyen mekanizmalar, olayları ve fikirleri algılarken de geçerlidir. Yerli ve yabancı örfler, tabular ve ilişkileri algılarken onlara belirli anlamlar yükleriz. Bunu yaparken özel bir gayret sarf etmeyiz. Alg mekanizmalarımız bunları organize eder. Bu insan zihninin evrensel bir özelliğidir (D. Krech, R. S. Crutchfield, Sosyal Psikoloji, Ötüken Yayınları, İstanbul 1980, 109).

Bireyin iç dünyası, sadece onun algıları veya yaşantısının diğer unsurlarından ibaret değildir. Algıladığımız şeyler, düzenli olarak etrafımızdaki fizik objelere bağlı olmakla beraber, o anda orada mevcut olmayan objelere de bağlıdır. Dünyayı algılayış tarzımız, duyu organlarımız vasıtasıyla algıladığımız şeyler kadar hafıza, hayal etme ve fantezilerin sonucu olarak ortaya çıkmaktadır. Sosyal davranışı anlamak için bütün algıların, hatıraların, fantezilerin nasıl terkip edildiğini, bütünleştiğini ve kognitif yapıları nasıl organize ettiklerini bilmek gerekir.

Kognitif sahada nesneler sabit olarak algılanır. Bizde daha önceden algıladığımız olgulara aykırı olan hususlar, kognitif sahamızın temel yapılarını yeniden düzenlememizi gerektirir. Fakat kognitif sahamızda bir yeniden düzenleme meydana gelmez. Çünkü bizim daha önceki algılarımız sonucu oluşan kognitif sahamız, yeni olguları örgütler (asimile eder). Mesela bizde bir etnik ya da dini grubun kötü olduğuna dair kuvvetli bir kognitif saha varsa, bu etnik ya da dini gruba mensup olan herhangi bir birey ne' kadar iyi şeyler yaparsa yapsın, onu insanlık dostu olarak göremeyiz. Klasik koşullanma teorisi ile de açıklanan bu düşünme biçiminin toplumsal yaşam içinde farklı yansımalarını gözlemlemek mümkündür. Ratcliff siyah Amerikalı'ların devam ettiği bir kiliseye giren beyaz insanın sahip olduğu korkuların önceki öğrenmelerin etkisiyle ortaya çıktığını ve kognitif sahadaki değişimlerle bu korkular sayesinde başa çıkıldığını savunur (D. Ratcliff, Psychological Foundations of Multicultural Religious Education, Multicultural Religious Education, Religious Education Press, Birmingham Alabama, 1997, 103).

İnsanın aynı objelerle defalarca karşılaşması, onları şu veya bu şekilde değerlendirmesi, algılaması, tanıma isteği ve hislerinin harekete geçmesi, bunların devamlı, birleşik ve bütün bir sistem halinde düzenlenmesine yol açar. Birey bir obje ile karşılaştığı zaman çeşitli konulardaki inançları, duyguları ve davranış eğilimlerinden meydana gelmiş sistem, kognitif dünyasında hazırdır. İşte bu hazır olan şey, objeye karşı geliştirdiği 'tutum'dur (Krech, Crutchfield, Ballachey, 1983, 227). İnsanlarm sosyal davranışlarının arkasında bu tutumlar bulunur. Bir tutum, motivasyon, heyecan, algı ve öğrenme süreçlerinin, bireyin dünyasının bir yönüne ait 
devamlı bir organizasyonudur (E. Güngör, Değerler Psikolojisi, Amsterdam 1993, 19; Krech, Crutchfield, 1980, 180).

Tutumlar, oldukça organize olmuş uzun süreli duygu, inanç ve davranış eğilimleridir. Bu eğilimler diğer insanları, grupları, fikirleri, ülkenin diğer yörelerini ya da nesneleri konu edinirler (D. Cüceloğlu, İnsan ve Davranışı, İstanbul 1994, 521). Bireyin hayat tecrübesi artıkça ve kognitif dünyasına daha fazla obje girdikçe, tutumları da çoğalır ve onları algı dünyasının belirli raflarından birine yerleştirmeye çalışır. Böylece bireyin eylem ve davranışları kalıplaşır, önceden kestirilebilir ve istikrarlı hale gelir. Bu sebeple tutumlar kognitif dünyanın vazgeçilmez unsurlarıdır (Krech, Crutchfield, Ballachey, 1983, 227).

Tutumlar, tutum objesi hakkında önceden sahip olunan inançlarla karışır. Fakat bütün inançlar tutumların birer parçası değildir. Tutumların lehte ya da aleyhte belirli bir yönü bulunmakla beraber, inançlar nötrdür (zıddıyla kaim değildir) (Krech, Crutchfield, 1980, 180-181).

Bireyin bir konudaki inancı hayatındaki çeşitli tecrübeleri boyunca değişmeden sürerken, başka bir konudaki inancı ya da inançları nispeten geçici olabilir ve kolayca değişebilir. İnsanların bütün inançları aynı önemi taşımaz. Inançların ifade edilmeleri onların önemini gösterir. Bu açıdan tutumların kuvveti ile inançların kuvveti arasında fark vardır.

Mardin, toplumun inanç, bilgi ve dünya görü̧̧lerine şekil verenlerin simgeler kümesi olduğunu belirtmektedir. Söz konusu 'simgeler kesitinin kapsadığ 1 girişimler arasında toplum değerlerinin yeni nesillere aktarılması (eğitim), kainat görüşlerinin anlatılması (din), toplumu pekiştiren merasimlerin devamlılığını sağlama sayılabilir' (Mardin, Türk Modernleşmesi, İletişim Y., İstanbul 1995, 144).

Toplumların tarihi süreci içerisinde işlenmiş, kültürüne mal olmuş, kurumlar yoluyla sürdürülen bu simge kümeleşmeleri, toplumların 'kültür kodu'nu oluşturur. Simgeleştirme süreci hayatımızı doğrudan etkilemekte ve toplumu algılamamızda, iç dünyamıza mal etmemizde çok büyük önem taşımaktadır (A. Lundberg, C. Schrag, N. Larsen, Sosyoloji, Çev.: Ö. Ozankaya, Işın Yayıncılık, Ankara, 1985, C. I, 17-18). Esasen bizim günlük hayatımız, soyut düşüncenin çok az kullanıldığı bir hayattır. Hayatımız, değerlerimiz, duygusal tepkilerimiz ve kültürümüzün bize kazandırdığg davranışlarla doludur. Günlük hayatımızın kültürel muhtevalarından biri tarihi süreç içerisinde belli davranış çizgisini devam ettirmeye yarayan 'kültür kodu'dur. Diğeri, toplumsal hayatın teorik çerçevesinin dışına çıkan ve bizi bazı ritüeller etrafında birleştiren, bizi pratik olarak hayatın bizzat içine sokarak hayatı merasimler kümesi olarak idrak etmemize yol açan 'sosyal hayatın merasim içeriği'dir. Bu ritüel içeriğin ve simge kümelenmelerinin birleştiği, insan hayatının odak noktalarını teşkil eden önemli bir olgu da dindir (Mardin, 1995, 16-18). Din, kognitif dünyaya kattığı değerler ve simgeler kümesiyle hem toplumun bütünleştiricisi olarak fonksiyon görür hem de kültürel muhtevanın odak noktasını teşkil eder. Isşte 
insan, nesneleri, olayları ve fikirleri bu kognitif dünyanın anlamları çerçevesinde görmeye başlar.

Bireyin kurduğu bu kognitif dünya, onun toplumsal dünya ile etkileşimi sonucu gerçekleşir. Toplumsal dünya olduğu gibi kabul edilmeyi bekler. Sosyalleşme, bu olduğu gibi kabul edilme ne kadar içselleştirilirse o kadar başarılı olur. Toplumsal dünya olduğu gibi kabul edilince, bu dünyanın manaları, evrende mevcut olduğu kabul edilen manalarla birleşmiş olur. Toplumda beşeri olarak inşa edilen düzendeki manalar, evrene de yansitılır. Böylece toplumsal düzen istikrara kavuşmuş olur. Burada toplumsal düzenin istikrarı ile ilgili olarak yine din gündeme gelmektedir. Din, kendisiyle kutsal bir alemin kurulduğu insani bir girişimdir (Berger, 1993, 54-55).

Dinin, insanın dünya kurma girişiminde çok önemli rolü vardır. $O$, insanın kendi öz manalarını gerçekliğe aşılayarak sürekli dış dünyaya açılmasının son sınırını ifade eder. Ayrıca beşeri düzen, din yoluyla varlığın bütününe yansıtılır. Kısaca din, evrenin tamamını insan açısından manidar kılan ve insanın vazgeçemeyeceği bir olgudur (Berger, 1993, 77).

İnsanlık tarihi, aynı zamanda dinin gelişim tarihidir. Çünkü tarih kayıtları dinsiz bir toplumu göstermemektedir. Din ise toplumların hayatındaki önemli konumunu, çeşitli kılıklara girerek ve isimlere bürünerek sürdürmektedir. Dünya tarihi, toplumların bireye hakimiyetini sürdürmede, düzenlerini pekiştirmede ve önemli toplumsal değişimleri gerçekleştirmede dinle yaptıkları sayısız işbirliğine sahne olmuştur. Çünkü din bireyin hayatını anlamlandırma, sıkıntılarından sıyrılma, sığınma vb. gibi, başka hiçbir kimsenin, kurumun ve ideolojinin kendisine sunamadığ görmektedir. Bireyin, kendisine toplumsal ve iç dünyalar kurmasına katkıda bulunmaktadır. Din, özellikle modern toplumsal hayat içinde bireyin ruhunun en derin tabakalarına kadar nüfuz edebilmektedir. Modern hayat içinde dinin etki alanı daralmışsa da din, bireyin şahsiyetinin parçalanması tehlikesine karşı onu koruyan en büyük kalkan olmaktadır. Bu anlamda bütün dinler bireyin mutluluğunu ve huzurunu sağlama; insanın ve toplumun düşmanı eğilimler ve süreçlerden koruma, dünya hayatının sıkıntılarıyla daha güçlü bir şekilde başa çıkmasında ona yardımcı olma amacındadır.

Her toplumun dini, din anlayışı, kültürü, insan yetiştirme düzeni, idealleri, değerleri farklıdır. Dinlerin çıktıkları yolculukta amaçları, bireyi mutluluğa ulaştırmaktır. Fakat toplumların dinle çıktıkları yolculukta hangi durakta nelerle karşılaşacağı belli değildir. Çünkü toplumlar statik değildir, toplumda çeşitli kültür alanları birbiriyle devamlı etkileşim halindedir. Dinle karşılıklı etkileşimde toplumların, tarihin farklı dönemlerinde farklı gelişme mecralarından geçmesi tabiidir.

Din (İslam) de Türk toplumu içerisinde, dönemin şartlarına göre çeşitli dönüşümler geçirmiştir. Elbette bunlar Türk toplumunun geçirdiği dönüşümler çerçevesinde gerçekleşmiştir. Osmanlı'dan Türkiye Cumhuriyeti'ne geçiş ve yaşanan olaylar çerçevesinde dinin farklı anlaşılmalarına tanık olunmuştur. Ankara Úniversitesi Senatosu'nun bir 
İlahiyat Fakültesi açılması konusundaki kararından sonra 3 Mayıs 1949'da zamanın hükümeti meseleyi Türkiye Büyük Millet Meclisi'ne 'Din meselelerinin sağlam ve ilmi esaslara göre incelenmesini mümkün kılmak, mesleki bilgisi kuvvetli ve düşünüşünde ihatalı din adamlarının yetişebilmesi için lüzumlu şartları sağlamak maksadıyla...' gibi gerekçelerle getirmiş ve İstanbul Darü'l-Fünun İlahiyat Fakültesi'nin kapanmasından sonra Ankara Üniversitesi'ne bağlı İlahiyat Fakültesi kurulmuş, (M. Koştaş, Ankara Üniversitesi İlahiyat Fakültesi, A. Ü. İ. F. D., 1991, Özel Sayı, C. XXXI, 810) bunu diğer fakülteler takip etmiştir. Bu amaçlarla kurulan İlahiyat Fakülteleri'nden yetişen, İmam-Hatip liselerinde meslek derslerini; ilköğretim okullarında, liselerde ve meslek liselerinde Din Kültürü ve Ahlak Bilgisi dersini vermek üzere mezun olan, Diyanet İşleri Başkanlığı'nın çeşitli birimlerinde (müftülük, vaizlikten müfettişliğe kadar) istihdam edilen, İlahiyat Fakülteleri'nde akademik, bilimsel çalışmalar yapan, kısaca halkı dini konularda aydınlatması beklenen 'İlahiyat Fakültesi öğrencilerinin din anlayışını ortaya koymak' üzere tarafımızca bir ölçck geliştirilmiştir.

\section{B. YÖNTEM}

'Din Anlayışı' ölçeğini oluşturacak şekilde sorular düzenlenmiş, alan uzmanlarıyla istişareden sonra 31 soru tespit edilmiş, bu sorular Ankara, Marmara ve Atatürk Üniversitesi İlahiyat Fakülteleri'nin birinci ve son sınıflarında okuyan toplam 376 öğrenciye uygulanmıştır. Faktör analizinden sonra 20 soru ve üç faktörden ibaret bir veri toplama aracı ortaya çıkmıştır.

SPSS programındaki faktör analizinde veriler üzerinde önce temel bileşenler analizi (principal component analysis) yapılmı̧ ve rotasyon sonrası faktör sayısı ve faktör özdeğerleri ortaya çıkmıştır. Sonuçta 20 ölçek sorusundan ibaret, üç faktörlü bu veri toplama aracının, toplam varyansın \% 42.8'ini açıkladığı tespit edilmiştir.

'İlahiyat Fakültesi Öğrencilerinin Din Anlayışı Ölçeği'ni belirleyen boyutlar ortaya çıktıktan sonra bu boyutlarla elde edilen bulguların yorumlanabilir olup olmadığına Ki-kare Testi sonuçlarına bakılarak karar verilmiştir. Bu pilot araştırmada yapılan faktör analizine göre Bartlett Kikare: 1423,2 ; df: $190 ; P=0.001$ olarak tespit edilmiştir. Tüm ölçeğin Cronbach Alpha iç tutarlılık değeri ise 0.804 'tür. Her bir faktör için Alpha değeri ile faktörün açıkladığı varyans oranı faktör yük değerlerini gösteren tablonun altında belirtilmiştir.

\section{a) Faktörler ve Faktör Özdeğerleri}

“Illahiyat Fakültesi Öğrencilerinin Din Anlayışı Ölçeği”ni oluşturan faktörlerin isimleri, özdeğerleri ve ağırlıkları aşağıdaki tabloda görülmektedir. 
Tablo 1. İlahiyat Fakültesi Öğrencilerinin Din Anlayışı Ölçeği Faktör Özdeğerleri

\begin{tabular}{||l|c|c|c||}
\hline Faktörler & Faktör Özdeğerleri & Varyans Oran (\%) & Kümülatif \% \\
\hline Faktör 1=Gclencksel-IImihalci & 5.466 & 27,328 & 27.328 \\
\hline Faktör 2=Siyasal-İslamcı & 1,623 & 8.115 & 35.443 \\
\hline Faktör 3=Modernist & 1.264 & 6,318 & 41.762 \\
\hline
\end{tabular}

Extraction Method: Principal Component Analysis.

Faktör analizi sonucunda "İlahiyat Fakültesi Öğrencilerinin Din Anlayışı Ölçeği”ndeki maddeler üç faktör altında toplanmış ve ölçcğimizin faktör isimleri şu şekilde belirlenmiştir:

1. Geleneksel-İlmihalci Anlayış: W. Sumner tarafından ilk defa kullanılan 'folkway' terimi bizde 'halk tarzları' olarak çevrilmiştir. Fakat şu anda' yaygın olarak 'gelenek' anlamında kullanılmaktadır. Gelenekler, insanların gündelik hayatlarında uydukları, bir tür sosyal anlaşma temeline dayanan, basit bir takım uygulamalardır. Toplumsal dayanışmanın devamında önemli rolleri vardır (S. Dönmezer, Sosyoloji, İ.I.T.I.A. Nihad Sayar Yayın ve Yardım Vakfı Yayınları, No.: 299/526, İstanbul 1978, 244245). Dar anlamda gelenek, 'bir kimsenin bir şeyi algılaması, algıladığı şekli ile benimsemesi, tekrar tekrar yapması, alışkanlık haline getirmesi ve onu başkalarına aktarmasıdır (Aslantürk, Amman, 1999, 233). Sözlükte ise gelenek, 'belirli davranışsal norm ve değerleri benimseyip aşılayan, gerçek ya da hayali bir geçmişle süreklilik gösteren ve genellikle yaygın biçimde benimsenen ritüeller ya da başka sembolik davranış biçimleriyle ilişkili toplumsal pratikler kümesi' olarak tanımlanmaktadır (G. Marshall, Sosyoloji Sözlüğü, Çev.: O. Akınhay, D. Kömürcü, Bilim ve Sanat Yayınları, Ankara 1999, 258-259). Gelenekler çok defa belli konu veya sorular üzerindeki duygu ve tutumlarını düzenleyen güçlü araçlardır. Bireyde bir ödev duygusu, doğru-yanlış ve ahlaki erdem duygusu yaratır. Bir grup veya topluluğun canlılık ve istikrarı, bireylerin gelencklere uyma kararlılığında kendini gösterir. Geleneklere uymak grubun bireye, kendisinden beklenen davranışların neler olduğunu öğretmede başvurduğu yollardan biridir. Geleneklerin öğretilmesi başarıldığı zaman birey, grubun beklentilerine göre hareket etme konusunda bir ödev duygusu kazanır (Lundberg v.d., 1985, C. $\mathrm{I}, 125)$.

Gelenekler, yetkili organlar tarafından kararlaştırıldığında 'yasalar'a dönüşür (Lundberg v.d., 1985, C. I, 126). Gelenekler genellikle yasalardan daha geniş bir alanı yönetirler. Bütün gelenekler yasa halini almaz, bütün yasalar da gelenekler tarafından desteklenmez. Çünkü gelenckler kültüreldir, yörelere ve toplumsal kesimlere göre değişebilir. Böylece toplumun bazı kesimleri tarafından desteklendiği halde diğer bazı kesimlerince reddedilebilir. Oysa yasalar nispeten devamlı ve tek biçimlidir. Bu sebeple 
bir çok yasa, ilgili olduğu davranışlar artık geleneklerle desteklenmese bile yürürlükte kalmaya devam edebilir (Lundberg v.d., 1985, C. I, 128).

Topluluğun veya grubun devamı bakımından bu normatif ölçüler (gelenekler ve yasalar) çok önemlidir. Toplumun en temel ve önemli ihtiyaçları çerçevesinde örgütlenmiş olan ve yukarıda bahsedilen değerlerin, normların, geleneklerin, yasaların ve davranış kalıplarının bileşimi toplumsal kurumları oluşturur. Toplum üyeleri, kültürel özelliklerini ve varlıklarını devam ettirmek için bunlara sıkı sıkı sarılırlar. Toplum sosyal, ekonomik, külttürel ve siyasi bakımdan değiştiği, üyelerin ihtiyaçları farklılaşı̆̆ğı halde bazı toplumsal kesimler eski alışkanlık ve geleneklere daha fazla sarılıp, değişimlere direnmeye çalışırlar. Böylece bir gelenekçilik ortaya çıkar. Gelenekçilik, 'kültürün eski kuşaklardan miras olarak aldığı kısımlara dayanmak ve toplumda değişmelerin doğuracağı sarsıntılara böylece karşı koymak fikrini savunanların görüşü' olarak tanımlanır ve böyle bir sosyal tavrın bazen geçmişe bağlanmaya ve kültürün yeni kaynaklarına karşı koymaya kadar gidebileceği hatırlatılır (H. Z. Ülken, Sosyoloji Sözlüğüu, M. E. Basimevi, İstanbul 1969,115 ).

Geleneksel toplumlarda dinin çok önemli bir yeri vardır. Toplumun kültürel alanlarının bir çoğunun üzerinde etkisi vardır. Dinin kültür alanlarından soyutlanması ve etkisinin azalması, aydınlanma dönemiyle başlayan bir süreci ifade etmektedir.

Her toplumun bir kültürü vardır. 'İnsanın geliştirdiği araçlar, silahlar, mesken ve emtialar, üretim tekniklerinin geliştirilmesinden düşünce ve inanç sistemlerine, hukuk, devlet, ahlak, sanat, ilim dahil, felsefe, sosyal organizasyonlar ve kurumlara kadar ne varsa her şeyi kapsar' (Aslantürk, Amman, 1999, 196).

Toplum üyelerinin ihtiyaçlarına bulduğu çözümler sonucu oluşan ve onların insana, evrene, eşyaya, Tanrıya karşı tutumlarıyla şekillenen kültürleri, her nesilden bireyler tarafından tekrarlanarak kurumsallaşır ve sosyal verasete konu haline gelir. Bir malın üretim tekniği çabuk değişebildiği halde; inanç sistemleri, din gibi, insanın iç dünyasını anlamlandıran manevi unsurlar çok zor değişir. Söz konusu değişme ise o toplumda kültür alanlarının dinle karşılıklı ilişkisine göre şekil alır. Şu halde gelenekler, toplum üyelerinin çoğunluğunun, nesillerden beri tekrarladıkları, uyguladıkları, uydukları, el üstünde tuttukları değerler, davranış kalıpları, örf-adetler ve alışkanlıklarının sonucunda ortaya çıkar. İnsanın iç dünyasını anlamlandıran din de, önerdiği değer hükümleri ve koyduğu kurallarla geleneği destekleyebilir, hatta dinin kendisi geleneksel hale gelebilir. Fakat şunu söylemek gerekir ki her din, kuruluş aşamasında veya alternatif olarak ilk ortaya çıktığında yenilikçidir, yani geleneğe (eskiye) muhaliftir.

2. Siyasal-Islamcı Anlayış: Siyaset, devlet işlerine katılma ve devlet etkinliklerinin biçim, amaç ve içeriğini belirleme işidir (Ö. Ozankaya, Toplumbilim Terimleri Sözlüğü, Ankara 1984, 107). Sosyologların genel kabulüne göre toplum içerisinde altı temel toplumsal kurum vardır. Bu temel 
toplumsal kurumların biri de siyasettir. Siyaset kurumu, toplumların uzun yıllar devam eden yönetim tecrübelerinin sonunda devlet yönetimi konusunda kazandığı bilgi, tecrübe ve davranı̧ kalıplarını içerir (J. Fichter, Sosyoloji Nedir, Çev.: N. Çelebi, Attila Kitabevi, Ankara 1994, 74-76, 124125). Devlet ise belli bir toprak parçası üzerinde yaşayan insanların toplumsal örgütlenişini ifade eder.

Özellikle 1970'li yılların ortalarından sonra gündemimize girmiş olan 'Siyasal İslam' kavramı ülkelere, gruplara göre farklı anlamlara gelebilmektedir. İslam'ın siyasetle ilgili konularda belirli bir hükmü olup olmadığını anlamak için Kur'an'a bakmak yeterlidir. Kur'an'ın siyasal düzenlemelerle ilgili belirli bir hükmü yoktur. Kur'an'ın siyasi meseleleri insana bıraktığı, sadece bazı ilkeleri vazettiği anlaşılmaktadır. Bu ilkeler ise toplumda adalet (Kur'an; Nisa/58, Sa'd/26), şura prensibi (Şura/36-38), işin ehil ellere verilmesidir (Nisa/58).

İran'daki Humeyni devriminin, dünyadaki müslüman ülkelerde olduğu gibi ülkemizde de siyasal İslamcı hareketin güçlenmesinde etkili olduğu çok açıktır. İran devriminin kendisini 'İslam Devrimi’ olarak lanse etmesinden sonra İran, devrimi diğer ülkelere ihraç etmek istedi. Türkiye'deki çeşitli İslamcı gösterilere destek verdi. Türkiye'deki rejimi açıkça eleştirdi. Iran Meclis Başkanı Haşimi Rafsancani, yaptığı bir konuşmada 'Türkiye'nin bir İslam devrimi için olgunlaştığını' söyleyecek kadar işi ileri götürdü.

Bir taraftan İran, İslam adıyla süslediği devrimin radikal fikirlerini Türkiye'ye gönderdiği ajanları tarafından ülkemizde yaymaya gayret ederken, diğer taraftan içerideki İslamcı yazarların ithal ve radikal fikirlerinden etkilenen, hareketli ve hayatına bir mana alemi arayan gençlik bu fikirlerin büyüsüne kapılmış, İslam'ın sadece bir din değil, aynı zamanda bir hayat nizamı veya bir ideoloji olduğunu savunmaya başlamıştı. 'Radikal İslami hareketlerin dünyadaki zaferleri; ülkede devletin bürokrasi kadrolarını müslümanlara teslim etmesi; insanların dine (İslam'a) olan ilgilerinin birkaç sansasyonel hidayet vakasıyla daha da pekişmesi; laikliği savunduklarını söyleyen kesimlerin basının irtica kampanyalarının etkisiyle İslami hareketliliği abartması... Bütün bunlar, atılımların konjonktürel olabileceğini hesaba katmayan İslamcıların gözlerini kamaştırıyor, onları beklenen günün geldiğine inanmaya sevk ediyordu. Bu heyecan İslamcıların dinlerini daha çok politik bir ideoloji olarak algılamalarına ve bu şekilde tebliğ etmelerine neden oldu' (Ruşen Çakır, Ayet ve Slogan, Metis Yayınları, İstanbul 1990, 253-254).

3. Modernist Anlayış: Sosyologlar, Batılı olmayan toplumların geçirdiği bu değişim sürecini ifade etmek üzere bazen 'gelişme', bazen de 'modernleşme' kavramlarını kullanıyorlar. Modern kelimesinin kullanılması V. yüzyıla kadar gider. Latince 'modernus' olarak ifade edilen kelime Hıristiyan olan o dönemi, Roma ve Pagan geçmişten ayırmak için kullanılır. Eski olandan, 'yeni' olana geçildiğini belirtir (J. Habermas, Modernlik: 
Tamamlanmamı̧ Bir Proje (Çev.: G. Naliş), Derleyen: N. Zeka, Postmodernizm, Kıyı Yayınları, İstanbul 1990, 31)

Modernleşme kuramcılarından Eisenstadt ise modernleşmeyi, 'tarihsel olarak 17. yüzyıldan 19. yüzyıla kadar Batı Avrupa ve Kuzey Amerika'da geliştirilmiş olan toplumsal, ekonomik ve siyasal sistemlerin, diğer Avrupa ülkelerine ve 19. ve 20. yüzylllarda da Güney Amerika, Asya ve Afrika kıtalarına yayıldığı bir değişme süreci olarak tanımlar (S. Aydın, Modernleşme ve Milliyetçilik, Gündoğan Yayınları, Ankara 1993,23).

Modernleşme kuramları, aydınlanma geleneği içinde bir çerçeveye oturtulmuş, bugünü şekillendiren ve iç-içe geçmiş yapısal, kültürel, psişik ve fizik değişmeler karmaşasını açıklamaktadır. Bu değişimin somut yansımaları, artan kentleşme, dinin etkisinin azalması, düşünce ve eylemlerin akılcılaşıp dünyevileşmesi, demokratikleşme, toplumsal farklılıkların azalması, bireyin ön plana çıkması (M. Akgül, Türk Modernleşmesi ve Din, Çizgi Kitabevi, Konya 1999, 40-41) ve en önemlisi kütlevi üretim sağlayan endüstriyel kompleksler (H. Freyer, Industri Çağı, İ.Ủ.E.F. Yay. İstanbul 1954,6 ) olarak ifade edilebilir.

\section{b) İlahiyat Fakültesi Öğrencilerinin Din Anlayışı Ölçcği Faktör ve Madde Analizi Sonuçları}

Tablo-2 Geleneksel-İlmihakci Din Anlayıșı Faktör ve Madde Analizi Sonucları

\begin{tabular}{|c|c|c|c|c|c|}
\hline $\begin{array}{l}\text { Madde } \\
\text { No: }\end{array}$ & Soru & $\begin{array}{c}\text { Ortala } \\
\text { ma }\end{array}$ & $\begin{array}{l}\text { Standart } \\
\text { Sapma }\end{array}$ & $\begin{array}{l}\text { Faktör } \\
\text { Yük } \\
\text { Değeri }\end{array}$ & $\begin{array}{l}\text { Madde Topl } \\
\text { Korelasyonu }\end{array}$ \\
\hline 19 & $\begin{array}{l}\text { Her scy Allah'ın takdiri ile olur, } \\
\text { insan alın yazısını değiștircmez. }\end{array}$ & 3.64 & 1.29 & .47 & .3808 \\
\hline 27 & $\begin{array}{l}\text { İslam alimleri her konunun } \\
\text { fetvasını vermiştir. Artık o } \\
\text { konularda ictihada gerek yoktur. }\end{array}$ & 1.79 & .91 & .69 & .5020 \\
\hline 30 & $\begin{array}{l}\text { Gerçek İslam'ı yaşayabilmek ve } \\
\text { Allah'ın yolunu bulabilmek için } \\
\text { bir mürşide ihtiyaf vardır. }\end{array}$ & 2.81 & 1.23 & 62 & .5788 \\
\hline 31 & Sarık müminin şarıdır. & 2.17 & 1.09 & .66 & .6326 \\
\hline 34 & $\begin{array}{l}\text { Başı açı bir kadının bulunduğu } \\
\text { ycre melek girmez. }\end{array}$ & 2.36 & 1.08 & .48 & .4958 \\
\hline 35 & $\begin{array}{l}\text { Dinimize göre başı açık erkeklerin } \\
\text { sahitliği kabul edilmcz. }\end{array}$ & 1.59 & .88 & .60 & .4010 \\
\hline
\end{tabular}




\begin{tabular}{|c|l|c|c|c|c|}
\hline 39 & $\begin{array}{l}\text { "Kıyamet günü en siddetli azap } \\
\text { ressamlarındır" anlamındaki } \\
\text { hadistc ifade edilen fikre katılıyor } \\
\text { musunuz? }\end{array}$ & 2.63 & 1.04 & .51 & .5667 \\
\hline $\mathbf{4 0}$ & $\begin{array}{l}\text { Bir müslüman mutlaka bir } \\
\text { mezhcbe mensup olmalı ve ona } \\
\text { göre yaşamalıdır. }\end{array}$ & 3.23 & 1.27 & .62 & .5738 \\
\hline $\mathbf{4 2}$ & $\begin{array}{l}\text { Bir kişiyle arkadas ya da dost } \\
\text { olmak için aynı ideolojiden olmak } \\
\text { gcrekir. }\end{array}$ & 1.98 & .91 & .36 & .2830 \\
\hline $\mathbf{4 4}$ & $\begin{array}{l}\text { Kadının sesini erkeğe duyurması } \\
\text { haramdır. }\end{array}$ & 2.37 & 1.08 & .59 & .5474 \\
\hline
\end{tabular}

Açılklanan varyans: \% 18.3

Cronbach Alpha $=.8145$

Tablo-3 Siyasal-İslamcı Din Anlayıșı Faktör ve Madde Analizi Sonucları

\begin{tabular}{|c|c|c|c|c|c|}
\hline $\begin{array}{l}\text { Madde } \\
\text { No }\end{array}$ & Soru & Ortalama & $\begin{array}{l}\text { Standart } \\
\text { Sapma }\end{array}$ & $\begin{array}{l}\text { Faktör } \\
\text { Yük } \\
\text { Dcğeri }\end{array}$ & $\begin{array}{l}\text { Madde Toplam } \\
\text { Korelasyonu }\end{array}$ \\
\hline 22 & $\begin{array}{l}\text { Kur'an'daki hükümler her } \\
\text { çağda ve bütün insanlar için } \\
\text { geçerlidir. }\end{array}$ & 2.43 & 1.32 & .48 & .4368 \\
\hline 23 & $\begin{array}{l}\text { Namaz dinin direğidir ve } \\
\text { namaz kılmayan bir } \\
\text { müslümanın imanı zayıftır. }\end{array}$ & 4.13 & .97 & .67 & .3852 \\
\hline 24 & $\begin{array}{l}\text { Dostluk ziyaretlerinde vc } \\
\text { diğer görüşmelerde kadınla } \\
\text { erkeğin haremlik-sclamlık } \\
\text { oturması dinimizin gereğidir. }\end{array}$ & 3.42 & 1.21 & .64 & .5912 \\
\hline 37 & $\begin{array}{l}\text { Dine hizmet etmeyen gazetc } \\
\text { ve dergilere para vermek bir } \\
\text { müslüman için uygun } \\
\text { değildir. }\end{array}$ & 3.29 & 1.33 & .60 & .4979 \\
\hline 38 & $\begin{array}{l}\text { Heykel yapan put yapmıs, } \\
\text { heykele saygı gösteren puta } \\
\text { tapmıs olur. }\end{array}$ & 2.99 & 1.22 & .65 & $\begin{array}{r}4879 \\
.\end{array}$ \\
\hline 45 & $\begin{array}{l}\text { Kadının erkekle tokalaşması } \\
\text { haramdır. }\end{array}$ & 3.67 & 1.14 & .60 & .4788 \\
\hline
\end{tabular}

Açıklanan Varyans: \% 15.2 Cronbach Alpha $=.7412$ 
Tablo-4 Modernist Din Anlayışı Faktör ve Madde Analizi Sonuçlan

\begin{tabular}{|c|l|c|c|c|c|}
\hline $\begin{array}{c}\text { Madde } \\
\text { No }\end{array}$ & Soru & Ortalama & $\begin{array}{c}\text { Standart } \\
\text { Sapma }\end{array}$ & $\begin{array}{c}\text { Faktör } \\
\text { Yük } \\
\text { Dč̆cri }\end{array}$ & $\begin{array}{c}\text { Madde Toplam } \\
\text { Korclasyonu }\end{array}$ \\
\hline 26 & $\begin{array}{l}\text { Kur'anın mealini okumak } \\
\text { gerekir. Bu Allah’n Kur'anı } \\
\text { vahyctme amacına da } \\
\text { uygundur. }\end{array}$ & 4.53 & .83 & .56 & .1756 \\
\hline 28 & $\begin{array}{l}\text { Sadece erkeğin değil, kadının } \\
\text { da kocasını boşama hakkı } \\
\text { vardır. }\end{array}$ & 3.75 & 1.09 & .48 & .2317 \\
\hline 46 & $\begin{array}{l}\text { Cennetle müjdeleyen vaiz, } \\
\text { cehennemle korkutan vaizden } \\
\text { daha hayırlıdır. }\end{array}$ & 4.03 & 1.04 & .62 & 2130 \\
\hline 48 & $\begin{array}{l}\text { Kadının bir işyerinde çalısıp } \\
\text { ailesinin gelirine katkı yapması } \\
\text { dinimizce caizdir. }\end{array}$ & 3.87 & .97 & .74 & .3703 \\
\hline
\end{tabular}

Açıklanan Varyans: \% 8.3

Cronbach Alpha $=.4358$ 